\title{
Law and Justice for the Oceans: Study on Illegal, Unreported and Unregulated Fishing and Related Crimes
}

\author{
Aryuni Yuliantiningsih* ${ }^{* 1,2}$, Hartiwiningsih ${ }^{1}$, Ade Maman Suherman ${ }^{2}$, and Emmy Latifah ${ }^{l}$ \\ ${ }^{1}$ Law Faculty, Sebelas Maret University, Indonesia \\ ${ }^{2}$ Law Faculty, Jenderal Soedirman University, Indonesia
}

\begin{abstract}
This article examined the ethical and moral dimensions of Illegal, Unreported and Unregulated fishing and related crimes and explores the means to realize justice for the oceans. It needed a new paradigm for addressing the issues. The methods of discussion used statute approach and philosophical approach. Based on the research, it was known that IUU fishing related to other crimes and Transnational Organized Crime, so it was necessary to recognize the concept of transnational organized fisheries crime. The IPOA-IUU fishing and UNCLOS 1982 were not adequate to counter it. In the terms of ethics and morals, IUU fishing had violated the ecosystems ethics, the principles of sustainability, values of respect for human rights and justice for the oceans. Justice for the oceans can be realized with recognition of the ocean rights. It meant, the oceans was recognized had the equal position with humans. The oceans needed space to breathe and to breed for recovery itself. The legal consequences of the recognition of oceans rights, among others, extended the legal standing. It provided sanctions for perpetrators and provided obligations for States to protect the ocean rights.
\end{abstract}

\section{Introduction}

World consist of $70 \%$ oceans and all human being depend on it for water supply, foods, weather and air. Almost 50\% of population in the world straight depend on the ocean for livelihood, but the human activities drives it contaminated by the pollution, over exploitation, coastal degradation and the climate change, thus causes the ocean in crisis [1].The amount of human need and pressures toward ocean boost the extinction of such species and habitat such as fish, mangrove, seaweed and coral reef. The diversity of marine biota is being threatened, the marine ecosystem gradually lose its endurance. Currently, more than $70 \%$ of fish production comes from the stock which gets full exploitation, run over the ability of fish breeding in a sustainable manner [2].

The critical condition of the oceans due to the contamination is from the nature and human acts. The climate change may enlarge the impact of ecosystem damage caused by human activities such as air and water pollution [3]. The climate change may also destroy

'Correspondenceauthor: aryuni71@gmail.com 
othermarine ecosystem for instance the ecosystem ofsea grass, plankton even mangrove. The increase of rim temperature and unstable weather are the impact of the ecosystem damage thus the marine organism cannot adapt themselves to the change occurred [4].Currently, the ocean is in emergency situation due to the plastics waste. It is estimated that 275 million metric tons (MT) of plastics waste exist in 192 coastal of states with the total 4.8 to 12.7 million MT entering the oceans [5].As well as the damage rate of mangrove is $3-5$ times from the deforestation flow and the coral reefs damage in the world has $50 \%$ [6].

Other damage of ocean is caused by Illegal Unreported and Unregulated fishing (IUU fishing).According to the report of Food and Agriculture organization (FAO), IUU fishing acts has decreased the world fish stock as much $90,1 \%$ and caused the global lose up to 26 million tons of fish in each year[7]. Recently, the acts of IUU Fishing are being the entrance of other crimes and Transnational Organized Crime (TOC). Pursuant to the report of United Nations Office on Drugs and Crime (UNODC) 2011,says that the activity in fishery sector pertain to the transnational crimes are, human trafficking, people smuggling, illicit drug, corruption, and piracy [8]. The relation of illegal fishing activity with TOC and other crimes occur in several states. Environmental Justice Foundation (EJF) and Green Peace have also conducted a study in West Africa, sub Antarctic waters, Samoa, and Thailand. The crews on the ship of IUU fishing got physical and mental persecution, murder, being servitude without sleep or foods, not paid and being the victim of human trafficking [9].

According to the facts above, Indonesian government argues that IUU fishing is not only concerning the stealing fish and simply endanger the food sustainability, but also negatively affect the economy, harm the environment, and violate the human rights. IUU fishing is not solely being national problem as well as being the global enemy thus the international contribution is necessary to solve that.

Human exploitation toward marine resources and human in the fishery business cycle shows that the anthropocentrism ethics simply rooting. Anthropocentrism ethics always exalts that ethics is only for human, not for biotic and abiotic. This ethic then creates the dominated relation of human on nature, which end up on large exploitation for human interest in short time [10]. This anthropocentrism paradigm is necessary to be changed to realize the justice in ocean. The eco-centrism ethics which argue that nature is not an object but have equal position with human being the ideal ethics to be applied. To get over the crisis occurred in the ocean, on June 2016 in the event of United Nations Ocean Conference, Indonesia proposed to admit the Oceans Rights. According to the Ministry of marine and Fishery Indonesia, Susi PudjiAstuti, ocean should be given the rights as human to realize the justice for ocean [11]. This idea is restated at the World Ocean Day in 2017. The acknowledgement of Ocean rights certainly has important legal impact for the ocean and necessary to conducted further reviews. The current paper has two purposes, first is reviewing the dimension of ethics and moral in IUU fishing practices and related crimes, and second is reviewing the ways to realize the justice for ocean as one of the ecosystems should be maintained.

\section{The Dimension of Ethics and Moral in IUU Fishing Practices Related to Other Crimes}

Fishery is the source of foods, nutrient, income, and the livelihood of hundred million people in the world. Although it has always been recognized that due natural resources may be run out, but until today the fishery resources, treated as will never run out and continually exploited, by not much consider the consequences on the environment. By the higher the demand on fishery product, the states around the world are faced to the doubt of 
the facts that fishing does in over exploitative way, gradually will decrease the potential of fish resources preservation. The phenomenon of over fishing and habitat damage will be the causes of decrease the fish production supply.

In overcoming the international demand which continually increase, the fishery entrepreneur sometime conducts the IUU fishing by waiving the moral and ethics as well as violates the human rights.

The principle of ethics and consideration on fundamental of human values in fact is the heritage from natural laws doctrine. The values of this universal ethics and moral principles have succeeded to be taught in community. The universal ethics and moral values beside contain the universality and honour as well as are being flexible and eternal. These noble and great values that radiates and its function is to animate the norms of laws or other norms which real and factual applied and bound the international community [26].

Table 1.Dimensions of the ethics of fisheries

\begin{tabular}{|c|c|}
\hline Subject & Objective \\
\hline Ecosystem & Ecosystem well-being \\
\hline Fish stocks & Conservation \\
\hline Fisheries & Responsible fisheries,sustainable development \\
\hline Fishers & Safety on board, freedom and well-being, just access \\
\hline Fishing communities & Eradication of poverty, cultural diversity \\
\hline Consumers & Right to food, food safety \\
\hline
\end{tabular}

\section{Source: FAO}

FAO have formulated the Code of Conduct for Responsible Fisheries (CCRF) in the 28th conference of Committee on Fisheries (COFI) of FAO in Roma on 31 October 1995, attached on the resolution Number: 4/1995. This governance is the guidance for the national and international efforts to guarantee the implementation of conservation aspect, management and effective development of the aquatic biological resources by ecosystem sustainability and biological diversity. The background of CCRF establishment is one of them because the rising of IUU fishing globally.

The ethics in fishery field is related to the environmental ethics which may be the reference for the states and entrepreneur in utilizing the natural resources, particularly the marine resources. Environmental ethics is the basic morality that gives references in responding all things pertain to the environment as a unity in supporting the human living continuity. Human, natural resources and environment whether biotic or abiotic are the environmental community. All citizens of the environment interact with each other to produce a life. The relation among those environmental unsure should be in justice, as stated by Briant Baxter as ecological justice [12].In the relation between the human to human and human to non human in the context of ecological justice containing two important aspects those are distributive justice on environmental benefits(the justice distribution of environmental benefit) and the environmental justice itself. Similar opinion has been stated by David Scholsberg who says that ecological justice is the implementation of justice concept toward the ecological aspect which the core is the justice in the relation between human to human and human to non human[13].

Discussing the widespread practices of IUU fishing in the world, may be attributed to the growing doctrine in the marine laws history. Legal thinking of Romans against the 
oceans is based on the doctrine of res communism omnium (the common rights for mankind), which views the oceans use is free or open to everyone. The principle of res communist omniumin addition to the interest of voyage, become the basis for freedom in fishing [14].This doctrine is reinforced by the opinion of Grotius who fought for the principles of freedom in the ocean that is mare liberum which views that marine utilities based on the concept of freedom of the sea [15]. The doctrine of mare liberum has been recognized for long time and accommodated in United Nations Convention on the law The Sea 1982 (UNCLOS). All states have rights to utilize the ocean and the freedom which is recognized internationally as regulated on Article 87 UNCLOS, including the freedom in sailing and fishing.

In its development, the population of fishes which is initially considered to be unlimited then realized that it becomes threatened by the sophisticated fleets and fishing gears. The increase fishing intensity one of them is due to the IUU fishing practices. IUU Fishing is a global issue necessarily to be addressed seriously because it drives the economic losses of states in the world that have high dependence on fisheries [16]. According to the research of Agnew et.al., states that there are 11-26 Mmillion Ton fishes captured by IUU fishing practices, which when converted to be currency can generate the values about US\$10-30 billion. The values are quite large, given that the global economic contribution of fisheries sector is about $\$ 217$ billion [17]. While FAO states that $90 \%$ of the world's fish supply have been over-exploited [18].

Recently, the Illegal Fishing practice has been changed its operation system if compared to the operation system in 1990ies. IUU practices have been a highly sophisticated form of transnational organized crime, with the characteristics of modern ship's moving control and modern fishing gears [19].On the report in 2011, United Nations Office on Drugs and Crime (UNODC) says that the fisheries sector not only undertake the environmental crime but related to the transnational crimes for instance human trafficking, smuggling, drugs trading, corruption and piracy [20]. IUU fishing is also the firth of crimes toward human rights due to the most of the crews used by IUU Fishing ship are the victim of human trafficking and servitude (forced labour). In addition, according to the report of Environmental Justice Foundation (EJF) and Green Peace the relation between IUU fishing and TOC and other crimes occurred in several areas such as West Africa, Sub Antarctic waters, Samoa, and Thailand, and Indonesia. The crews on the ship of IUU fishing got physical and mental persecution, murder, being servitude without sleep and foods, not paid and even being the victim of human trafficking [21].

IUU fishing not only leads to overfishing, but also harms the marine environmental, depletion of fish supply and threatens fisheries sustainability, and the worst threatening the fisherman's living that depend on ocean. The activities of large fishing boat carried out simultaneously with the demand for cheap seafood. There is a correlation between the cheap market price, overfishing, IUU fishing, and the human rights violation, particularly the human trafficking and servitude. As has been occurred in Thailand which has been observed by EJF that international demand for cheap seafood leads to the continue the brutal human trafficking in vulnerable and ruin the whole marine ecosystems. Crime in fishing industry also occurred in Indonesia. On March 2015, Associated Press released its research about the relation of human trafficking on fisheries industry in Benjina, Indonesia. According to the investigation result, found the violations of human rights in the form of child labour, human trafficking, living condition under the standard, physical and mental persecution, works for 18-20 hours per day, works without any fees and fraud committed by PT Pusaka Benjina Resources (PT PBR).

The impact of IUU fishing practices and related crimes have leaded the failure in protecting the marine biodiversity and human rights[22]. Endangered human rights for instance the right to life (provided for Article 6 the International Convention on Civil and 
Political Rights), the right to organize, the rights to be free from the persecution and other inhuman or degrading treatment (Art 7 ICCPR), the right to be free from servitude and forced labor (Art.8 ICCPR), the right to work in good condition (Art. 6,7,8,9 of the International Covenant on Economic, Social and Cultural Right/ICESCR), the right to be healthy (Art. 12 ICESCR), the right to get healthy environment (Art. 12.2 ICESCR) and the right to access the foods (Art.11 ICESCR). The organized crime networks are also involved in illegal fishing- whether directly or indirectly in illegal fishing or catching endangered fish species.

The facts about violations of environmental ethics, moral and human rights values pertain to IUU fishing have proven the truth of Garret Hardin's opinion who said that a principle of common ownership has negative impact. In 1968 the United States ecologist, Garrett Hardin, released his article entitled "The Tragedy of the Commons". He argues that the tragedy of common ownership arise when everybody tries to take the natural resources that belongs together for personal interest thus harms other living being. Therefore, the tragedy of common Ownership generally occurs on resources that are public properties [23].This opinion initially favourable to those who use a lot of natural resources, but in the end its availability will be exhausted and will have negative impact for the users and other human, and over exploitation toward ocean will also occur. It causes endangered for a lot of marine species and harms the natural balance.

The perpetrators of IUU fishing have shown a tendency towards anthropocentrism ethics. Anthropocentrism is an ethic which argues that human is the core of system of universe. Anthropocentrism paradigm is considered as a shallow and narrow environmental ethic (shallow environmental ethics). Frit of Capra says that Shallow Ecology is an ecology that put human being over or outer the nature, in dominated position against the nature [24].

Anthropocentrism paradigm has caused the ocean as natural resources particularly fisheries become the human object. It is supported by the principle of freedom in the ocean one of them is freedom of fishing and the principle of common ownership. Certainly it occurs due to the anthropocentrism ethics that quiet rooted. Anthropocentrism ethics is too exalting that ethics are only for human being, not for biotic and abiotic nature. This ethic then creates the relation of human domination against the nature, which ends up on the massive exploitation to nature for short-term human benefits. Illegal fishing practice and other crimes related contrary to the principles of sustainable fisheries and human rights respect.

The main issue of ethic in fisheries widely related to the human ecosystem welfare. According to the ecological justice that there is should be a justice in natural utilization and justice on the natural resources itself. It may be realized in justice based on the principle of sustainable development that is formulated in the justice of intra-generation and intergeneration. Intra-generation justice is aimed to whom live in one generation. It is related to the natural resources distribution fairly applied on national level and/or international level. While inter-generation justice is related to the sustainable fisheries meant that in carrying the natural use, particularly fishing, should consider the future generation so that massive exploitation is not necessary.

The entrepreneur in fisheries should have the ethic of eco-centrism. The eco-centrism paradigm holds that, living creatures and other abiotic objects are intertwined with one to another. The moral responsibility and liability not limited on living creatures, but also applied on all ecological reality. Arne Naess, a Norwegian philosopher, who is one of the figures of eco-centrism paradigm, propose a view known as Deep Ecology. This view is a new ethic which is not human-centred, but centred on all living creatures in relation to address the environmental problems [25]. 
Respecting the nature is the basic principle for human as the part of universe, who should respect each species in ecological community as well as have moral responsibility to maintain the integrity of ecological community.

\section{Laws and Justice for Oceans Related to the IUU Fishing and Other Crimes}

Laws and justice cannot be separated and are the fundamental to common life [27]. Common life not only human should be treated fairly but all environments have the same right to be fairly treated. There are international laws regulating the liability of State in conserving the environment, including the Declaration of Stockholm 1972,United Nations Convention on the Law of The Sea1982 The Convention on Biological Diversity (CBD) in 1992 and International Plan of Action- IUU (IPOA-IUU) fishing released by FAO.

Stockholm Declaration considers the public views and principles for assisting human in preservation and improvement the human environment. In 1982, international community has agreed the UNCLOS that provide the marine issues comprehensively. This agreement provides for instance the maritime boundaries, rights and liabilities of State in ocean use, marine resources management, also protection and preservation of ocean. Moreover, there is Convention on Biological Diversity (CBD) in 1992. CBD is trigger due to the concerns about the pace of development, which, in the other hand leads to endanger many species. To stop the severe damage required an agreement governing the biological resources. This convention has three main goals those are, to conserve the biodiversity, to harness sustainable biodiversity, and to ensure fair sharing of benefits from the utilization of genetically sources. Furthermore, in 2001, FAO published IPOA IUU-Fishing. IPOA-IUU fishing is the global action aimed to prevent the fishery resources damage and redevelop the fishery resources which have been or almost extinct, thus the food demand sourced from fisheries for the current and future generation remain guaranteed the availability. Although there are UNCLOS 1982 and other regulations that provide the State's responsibility to conservee the marine resources, maintain the marine resources and environment, not accommodate the right of marine yet because UNCLOS 1982 more set the State's authorities to manage and utilize the marine resources.

Until now, IUU fishing remains be the global and crucial issue to be addressed because have been evolved into transnational and organized crimes so that in the current paper used the term of IUU fishing and related crimes. IUU fishing and related crimes have violated the ecological justice, principle of sustainable and human values so that new concept is required to be addressed. There are two new concepts being fought by Indonesia to address that issue. First, Indonesia is mainstreaming the acknowledgment of fisheries crimes as TOC transnational organized fisheries crime (TOC) in order to easier the international corporation in enforcing the laws [28]. Second, Indonesian government is mainstreaming the concept of ocean rights in United Nation to protect the ocean and realize the healthy oceans. This concept holds that the ocean can be recognized as the subject of laws that has the rights so that the position may be synchronized to human. Ocean requires space for breathing and breeding thus it may be recover.

The concept of ocean rights is inline with the opinion of Cristopher D. Stone who proposed the idea of making the environment as the subject of laws in 1972 on his article entitled; "Should Trees Have Standing? Towards Legal Rights for Natural Object". Stone argues that it is necessary to give legal rights to the natural objects such as forests, oceans, rivers, mountains as natural object which deserves the legal rights. Furthermore, according to Stone, environmental organization that have data and reason to suspect a project/activity will ruin the environment, that organization may propose to the court to be appointed as 
guardian of that natural object to supervise and manage natural objects against the indication of legal rights violation [29].

Most States in the world including Indonesia acknowledge that become the subjects of laws are human and legal entities, but in its development, environment as the subject of laws has been acknowledged in the constitution in several states of Europe, America, such as Portugal, Franch and Ecuador. [30].For example Article 72 of Ecuador Constitution provides that "Nature has the right to be restored. This restoration shall be apart from the obligation of the State and natural persons or legal entities to compensate individuals and communities that depend on affected natural systems". In the Europe union agreed that the UNECE Convention on Access to Information, Public Participation in Decision on Making and Access to Justice in Environmental Matters (Aarhus Convention). This convention is the first international instrument that regulates the procedure of rights in the context of environment and conceptualizes the access to environmental justice for the perpetrators not States.

The idea promotes the importance of ocean rights for all States, which have ocean and its resources, due to by several things. First, more massive crimes that exploit the marine resources sequent from IUU fishing, marine and coastal pollution due to industrial activities to the trade of marine biota protected. Second, the absence of adequate international legal shade and recognizes the importance of marine rights as the part of widest world ecosystem. Third, the dependency most people in the world toward marine space, ecosystem until the resources content as the transportation line, food and energy supply, as well as other services provider.

The acknowledgement of ocean rights in United Nations certainly is not easy because it must through the long procedures and supported by $2 / 3$ states who attends the UN General Assembly session. The form of acknowledgement may be set forth in a UN resolution. The legal impact if oceans rights recognized by international community for instance: first, the expansion of lawsuit, second, sanctions for violators, and third is the obligation for States to protects those rights.

The expansion of lawsuit may take the form of standing law. It is a legal product that gives individual, group/organization or governmental agencies access to justice as the plaintiffs to demand the restoration of their rights that have been violated. In Law number 32 of 2009 concerning the Environment, access to the rights is granted to several parties, those are, 1. Individual lawsuit (individual); 2. Non Governmental Organization's lawsuit (NGO standing), 3 group representative's lawsuits (Class action) and 4. Government and Local authorities lawsuit and Citizen's lawsuit.

In the context of ocean rights, NGO may perform in the court based on the understanding that NGO is the natural guardian. It is appropriate with the theory proposed by Stone that gives legal right to the natural objects. According to Stone, forests, oceans or rivers as the natural object are deserved to have legal rights and unwise if considered otherwise just because the inanimate characteristic (unable to speak). As the guardian, the court give rightts to NGO to monitor even manage those natural objects. In international laws, the lawsuit is a challenge if associated to the mechanism of overcoming of environmental and marine laws disputes.

The second legal impact is the provisions of sanctions for the violators. The sanctions in environmental laws context are administration, criminal, and civil sanctions. The administrative sanction is important for restoration of damaged or polluted environments and restoration of circumstances. Discussing the imposition of sanction in international laws should through long mechanism. If the violation concerning the issue of maintaining international peace and security then under Article 25 of UN Chartered authorized to impose the sanctions is the UN Security Council. However, if the violation is related to the marine environmental disputes then it may proposed to several international court for 
instance International Tribunal on The Law of Sea (ITLOS), International Court of Justice and International Arbitration agencies. This mechanism is necessary to be reviewed further because the agencies for addressing this dispute determine that only the State that may be the party to suit the dispute.

The third legal impact is the emergence of State's liability to protect the marine rights. The acknowledgement of ocean rights can be set forth in General Assembly resolution. General Assembly is main part of UN consisting all member States that may take the role in forming the international laws sources of resolution. Although the resolution of General Assembly is not legally binding, it creates the moral liability to the States to agree on it. The resolution also may help creating the international consensus and put the basic for subsequent binding agreement negotiations [33].

\section{Conclusion}

IUU fishing has become the entrance to other crimes and TOC such as, human trafficking, migrant smuggling, corruption, illicit drugs, servitude and human rights violation thus the term used in the current paper is IUU fishing and related crimes. The fisheries resources exploitation followed by the human rights violation in fisheries business indicates that the economy perpretators remain use the anthropocentrism paradigm. Viewed from the dimension of ethics and morals, the values of ethics and morals violated are for instance ecocentrism ethics, principle of sustainable, and the values of respecting human rights. The instrument of international laws such as UNCLOS 1982 and IPOA- IUU fishingare not adequate anymore to overcome the IUU fishing and related crimes so that required the criminal court system to address it. Indonesia is mainstreaming the recognition of concept of Transnational Organized Fisheries Crime in UN in order to easier the law enforcement to overcome the IUU fishing and related crimes. The crissis occurred in ocean requirred a solution to realize the justice for the oceans. The solution fought by Indonesian government is the acknowledgement of ocean rights. It will give important legal impacts for the ocean, move aside the paradigm of anthropocentrism that put the human as the subject and natural resources as the object become ocean in ecosystem equal to the human that have légal right, enlarge the lawsuit, the State may apply the sanction for the violators al well as determine the liabilities for the States to protect that law suit.

\section{REFERENCE}

1 UNESCO, Healthy Ocean, Healthy People, (UNESCO, France, 2010). PDF Available onhttp://unesdoc.unesco.org/images/0021/002166/216651e.pdf

2 Southern Ocean Conservation Unit,Aust. Antarctic Mag. 5 (2003)

3 M.A. Santosa, Penegakan HukumTerhadap PenangkapanIkanIlegal OlehKapalIkan Asing di ZEE Indonesia, Paper has Presented in Focus Group Discussion of Penegakan HukumTerhadap Penangkapan Ikan Ilega lOleh Kapal IkanAsing di ZEE Indonesia Universitas Indonesia,October, 24 (2017)

4 UNODC, Transnational Organized Crime in Fishing Industry, (Vienna,2011). PDF Available on:http://www.unodc.org/documents/human-trafficking/Issue Paper_TOC in the Fishing Industry.pdf

5 B. Islam, Int. J. Chem. Sci.: 11,3(2013)

6 J. R. Jambeck,et all, Sci. 347, 6223(2013)

7 FAO, The State of the World Fisheries and Aquaculture, (FAO, Rome, 2016). PDF Available onhttp://www.fao.org/3/a-i5555e.pdf 
8 Anonim,Global implication of IUU fishing, (NIC WP, 2016). PDF Available onhttps://fas.org/irp/nic/fishing.pdf

9 UNODC.Transnational Organized Crime in Fishing Industry, (UNDOC, Vienna, 2011)

10 EJF. All At Sea The Abuse of Human Rights Aboard Illegal Fishing Vessel. (Environmental Justice Foundation, UK, 2010)

11 EJF, Pirates and Slaves: How Overfishing in Thailand Fuels Human Trafficking and the Plundering of Our Oceans, (Environmental Justice Foundation, UK, 2015)

12 A. Satria, KrisisLautDunia, (Kompas, Senin, 08 Juni 2015), Available onhttp://pkspl.ipb.ac.id/berita/detail/krisis-laut-dunia, Accessed March 25, 2018.

13 B. Kuncahyo, Indonesia has urgued the United Nations to Issue Rights of Oceans, (Antaranews, 11th August 2017), Available on https://en.antaranews.com/news/112232/indonesia-urges-un-to-issue-rights-of-ocean, Accessed Mach 25, 2018

14 B.Baxer, A Theory of Ecological Justice(Routledge, London,2005)

15 D. Scholsberg, Defining Environmental Justice: Theories, Movements, and Nature,(Oxford University Press, New York, 2007)

16 A. Kiss, Int'l. J. Law, Int'l Comm.40,3 (1985)

17 J. Theutenberg, Artic.37, 4 (1984)

18 Anonim, Closing the net:Stopping illegal fishing on the High Seas, Final report of the Ministerially-led Task Force on IUU Fishing on the High Seas, (IUU Fishing Coordination Unit, UK, 2006), PDF Available onhttps://www.oecd.org/sdroundtable/papersandpublications/39375276.pdf

19 D. Agnew, et.all, Plos One, 4, 2(2009)

20 FAO, The State of the World Fisheries and Aquaculture (FAO, Rome, 2014), PDF Available on http://www.fao.org/3/a-i5555e.pdf

21 Southern Ocean Conservation Unit, Aust. Antarctic Mag. 5(2003)

22 UNODC.Transnational Organized Crime in Fishing Industry, (UNDOC, Vienna, 2011)

23 EJF. All At Sea The Abuse of Human Rights Aboard Illegal Fishing Vessel. (Environmental Justice Foundation, UK, 2010). Available onhttp://ejfoundation.org/report/all-sea

24 Anonim, Tragedy in the Marine Commons: The Intertwined Exploitation of Ocean Ecosystems and Fisheries Workers, Human Right at Sea. (2016). Available onhttps://www.ohchr.org/Documents/Issues/Environment/Biodiversity/CoalitionNGO s.pdf (Accessed February 16, 2018)

25 G. Hardin,Sci. 162, 3859(1968)

26 W. Ambrosius,UWL Undergraduate Research Journal, VIII (2005). PDF Available from https://www.uwlax.edu/urc/jur-online/PDF/2005/ambrosius.pdf

27 M.P. Nelson, Deep Ecology, Encyclopedia of Environmental Ethics and Philosophy. 207(2008). PDF Available onhttp://www.uky.edu/ OtherOrgs/AppalFor/ Readings/240\%20-\%20Reading\%20-\%20Deep \%20Ecology.pdf

28 D. Shelton,in Malcom D. Evans (ed). 70, 166(2014)

29 A. Carty. Philosophy of International law, (Edinburg University Press,Edinburg, 2007)

30 C.D. Stone. Southern. Cal. L. Rev.45, (1972)

31 H.Tenggono, Lingkungan Sebagai Subjek Hukum Dalam Mengatasi Permasalahan Lingkungandi Indonesia. Available on http:/www.academia.edu /17549482/ Lingkungan Sebagai Subjek Hukum 
32 A. Pramudianto, HukumLingkunganInternasional (Raja GrafindoPersada, Jakarta, 2017) 